\title{
The role of selectins in alopecia areata
}

\author{
Wiesława Sudnik ${ }^{1}$, Aleksandra Dańczak-Pazdrowska ${ }^{1}$, Wojciech Silny², Agnieszka Osmola-Mańkowska ${ }^{1}$, \\ Jakub Pazdrowski ${ }^{3}$ Adriana Polańska ${ }^{4}$
}

\author{
'Department of Dermatology, Poznan University of Medical Sciences, Poznan, Poland \\ Head of Department: Zygmunt Adamski MD, PhD \\ ${ }^{2}$ Great Poland Center of Allergology and Aesthetic Dermatology "Art Clinic", Poznan, Poland \\ Head of Center: Prof. Wojciech Silny MD, PhD \\ ${ }^{3}$ Department of Head and Neck Surgery, Poznan University of Medical Sciences, Poznan, Poland \\ Head of Department: Wojciech Golusiński MD, PhD \\ ${ }^{4}$ Department of Dermatology and Venereology, Poznan University of Medical Sciences, Poznan, Poland \\ Head of Department: Ryszard Żaba MD, PhD
}

Postep Derm Alergol 2015; XXXII, 1: 27-32

DOI: $10.5114 /$ pdia.2014.40946

\begin{abstract}
Introduction: One of the main histopathological features of alopecia areata (AA) is a lymphocytic infiltration that surrounds hair follicles. Soluble forms of E, L, P-selectins are known indicators of ongoing inflammation. There are no studies regarding the assessment of their contribution in AA.

Aim: To assess serum concentrations of selectins (E-selectin, L-selectin and P-selectin) in patients with AA in relation to selected clinical parameters, including disease severity and activity.

Material and methods: Sixty-four patients with AA were involved in the study. The diagnosis was based on physical examination and photodermoscopy. The control group consisted of 40 healthy subjects. The serum concentrations of soluble E-selectin, L-selectin and P-selectin were detected with ELISA method.

Results: Statistically significantly higher levels of E, P, L-selectins were found in AA patients as compared with the healthy group. Serum concentrations of soluble forms of E- and L-selectins correlated with the severity of the disease, while E-selectin with activity of AA.

Conclusions: This study shows that selectins may play an important role in the pathogenesis of AA and may be a target of future therapies in this disease.
\end{abstract}

Key words: alopecia areata, E-selectin, P-selectin, L-selectin.

\section{Introduction}

Alopecia areata $(A A)$ is a reversible, immunologically mediated syndrome, causing the destruction of hair follicles and subsequent immediate hair loss. The disease has usually long-term duration and because of its chronic nature significantly reduces the patient's quality of life. Etiology and pathogenesis of the disease has not been fully elucidated. It has been suggested that damage to the hair follicle occurs in connection with the surrounding lymphocytic infiltration, which was observed in histopathologic examination $[1,2]$. Another pathogenetic factor is associated with impaired angiogenesis [1-3] with a crucial contribution of selectins. E-selectin is considered as one of the major markers of endothelial cell damage, while soluble forms of E-selectin, L-selectin and P-selectin are considered as indicators of ongoing inflammation [2].

Significance of selectins was mainly assessed in psoriasis, but their abnormal serum concentration have also been demonstrated in systemic lupus erythematosus, scleroderma, urticaria, eczema, lichen planus, bullous pemphigoid, pemphigus vulgaris, graft versus host disease [4-22]. There are still no studies regarding the assessment of serum concentrations of soluble E-selectin, L-selectin and P-selectin forms in patients with AA.

\section{Aim}

Therefore, the main objective of this study was to assess serum concentrations of selectins (E-selectin,

Address for correspondence: Adriana Polańska MD, PhD, Department of Dermatology and Venereology, Poznan University of Medical Sciences, 49 Przybyszewskiego St, 60-355 Poznan, Poland, phone: +48 516123 858, e-mail: adriana-polanska@wp.pl Received: 25.10.2013, accepted: 7.11.2013. 
L-selectin and P-selectin) in patients with AA in relation to the control group. Additionally, the analysis of correlations between selectins (E-selectin, L-selectin and P-selectin) and selected clinical parameters, including the severity of the disease and its activity were evaluated.

\section{Material and methods}

Sixty-four patients with AA were involved in the study. There were $67.2 \%$ of women (43 patients) and $32.8 \%$ of men (21 patients). The average age of patients was 31.8 \pm 15.9 years. $62.5 \%$ of patients presented AA circumscripta (AAC), while $37.5 \%$ were diagnosed with alopecia totalis and alopecia universalis (AT/AU, respectively). The characteristics of the entire study group are presented in Table 1.

The diagnosis of AA was made on the basis of physical examination and photodermoscopy [23-25].

The patients with co-morbidities other than autoimmune diseases associated with AA, as well as patients receiving systemic treatment in the last 6 months (e.g. corticosteroids, phototherapy, cyclosporine A) were excluded from the study. In addition, patients treated in the last 6 months with antihistamines or vascular drugs (e.g. vitamin K antagonists, heparin, aspirin, ticlopidine, clopidogrel, pentoxifylline, diosmin) due to their ability to affect the concentration of soluble forms of selectins [26] were also not enrolled to the study.

The control group consisted of 40 healthy subjects. In this group, women accounted for $57.5 \%$ of individuals and men for $42.5 \%$. The average age in this group was $32.8 \pm 8.2$ years.

In physical examination, the number, extent and localization of the hair loss areas were evaluated with a detailed observation of the skin in close vicinity to affected regions. Dermoscopy was performed using photodermoscope Heine Delta 20 (Germany) and dermoscopic evaluation included assessment of features described in the literature [24].

In evaluation of disease activity the 3 months' time was taken into consideration. According to Olsen, the disease is active when in the last 3 months a new area

Table 1. Characteristics of patients with AA

\begin{tabular}{lcc}
\hline Parameter & Result \\
\hline Number of patients, $n(\%)$ & $64(100)$ \\
\hline Gender, & Female & $43(67.2)$ \\
\cline { 2 - 3 }$n(\%)$ & Male & $21(32.8)$ \\
\hline Age [years] & Mean \pm SD & $31.8 \pm 15.9$ \\
\cline { 2 - 3 } & Median & 33 \\
\cline { 2 - 3 } & Minimal value & 3 \\
\cline { 2 - 3 } & Maximal value & 62 \\
\hline
\end{tabular}

of hair loss appeared, or the expansion of the existing ones is observed $[23,27]$.

The serum concentrations of soluble E-selectin, L-selectin and P-selectin were detected with ELISA method using kits R\&D Systems (Minneapolis, USA): Quantikine Human sE Immunoassay kit (R\&D, USA), Quantikine Human SL Immunoassay kit (R\&D, USA) SP and Quantikine Human Immunoassay kit (R\&D, USA). Tests were performed in accordance with the methodology provided by the manufacturer. Measurements were performed with spectrophotometer EPOCH (Biokom).

\section{Statistical analysis}

The analyzed parameters such as measurable concentrations of selectins, age of the patients were described as arithmetic mean and standard deviation. Concordance between these parameters with a normal distribution was assessed with the Shapiro-Wilk test. The comparison between groups was made with $t$-Student test for independent variables. The homogeneity of variance was tested by Leven or Welch's test if variances were heterogeneous. When there was no evidence of compliance with the normal distribution, nonparametric Mann-Whitney test was used. The accepted level of significance was $p \leq 0.05$. The calculations were based on a statistical package Statistica (data analysis software system), v9 and Analyse, Microsoft Excel v2.20.

\section{Results}

The average concentration of the soluble form of E-selectin in AA patients was $39.1 \pm 17.5 \mathrm{ng} / \mathrm{ml}$. The average concentration of E-selectin taking into account the severity of the disease was $33.5 \pm 13.9$ in AAC $\mathrm{ng} / \mathrm{ml}$, whereas in AT/ $\mathrm{AU}$ it was $48.3 \pm 19.1 \mathrm{ng} / \mathrm{ml}$. In the healthy control group, the mean concentration of E-selectin was $27.7 \pm 12.1 \mathrm{ng}$ / $\mathrm{ml}$. The average serum level of the soluble form of E-selectin in patients with active AA phase was $48.0 \pm 17.5 \mathrm{ng} /$ $\mathrm{ml}$, whereas in the inactive phase it was $31.2 \pm 13.4 \mathrm{ng} /$ $\mathrm{ml}$. Statistically significantly higher levels of E-selectin were found in the AA group as compared with the healthy group $(p=0.0003)$ and in the group of patients with AAC $(p=0.0327)$ and AT/AU $(p=0.0001)$. There was a statistically significant difference in concentration of the soluble form of E-selectin between AAC and AT/AU patients $(p=0.0011)$. Statistically significantly higher concentrations of the soluble forms of E-selectin in the serum of patients with AA were observed in the active phase of disease in comparison to patients with inactive state $(p<0.0001)$.

The average concentration of the soluble form of L-selectin in the serum of all AA group was $1676.9 \pm 624.1 \mathrm{ng}$ / $\mathrm{ml}$ (Table 1). The average concentration of L-selectin in regards of disease severity for AAC was $1488.8 \pm 426.1 \mathrm{ng} /$ $\mathrm{ml}$, whereas for AT/AU it was $1990.3 \pm 771.3 \mathrm{ng} / \mathrm{ml}$. In the control group, the mean concentration of L-selectin was 
$1424.6 \pm 765.8 \mathrm{ng} / \mathrm{ml}$. The average serum level of the soluble form of L-selectin in patients with active AA phase was $1771.3 \pm 637.4 \mathrm{ng} / \mathrm{ml}$, whereas in the inactive phase it was $1593.6 \pm 609.4 \mathrm{ng} / \mathrm{ml}$. Statistically significantly higher concentrations of the soluble form of L-selectin in healthy subjects were found both in patients with AA $(p=0.0026)$ and in patients with AT/AU $(p=0.0005)$. However, comparison of serum concentrations of soluble form of L-selectin between AAC patients and healthy subjects showed no statistically significant difference ( $p=0.0543)$. Statistically significantly higher concentrations of soluble form of L-selectin were found in patients with AT/AU as compared to patients with AAC $(p=0.0063)$. There was a higher average concentration of soluble form of L-selectin in the serum of patients with $A A$ in the active phase as compared with the group of patients with AA in inactive phase, but the difference was not statistically significant $(p=0.1577)$.

The average concentration of soluble form of P-selectin in the serum of all patients with AA was $96.4 \pm 44.8 \mathrm{ng} / \mathrm{ml}$. The average concentration of soluble form of P-selectin taking into account the disease severity was for AAC 101.7 $\pm 50.5 \mathrm{ng} / \mathrm{ml}$, whereas for AT/AU, it was $87.5 \pm 32.3 \mathrm{ng} / \mathrm{ml}$. In the control group, the average concentration of soluble form of P-selectin was $77.6 \pm 20.8 \mathrm{ng} / \mathrm{ml}$. Average soluble form of the P-selectin serum level in patients with active phase of the disease was $88.3 \pm 34.8 \mathrm{ng} / \mathrm{ml}$, whereas in the inactive state it was $103.6 \pm 51.5 \mathrm{ng} / \mathrm{ml}$. Comparison of serum concentrations of soluble form of P-selectin between a group of AA patients and healthy subjects ( $p=$ $=0.0275)$ as well as a comparison between AAC patients and healthy volunteers ( $p=0.0153)$ showed significant differences. However, there was no statistically significant difference in the serum concentrations of soluble form of P-selectin between patients with AT/AU and healthy subjects $(p=0.1842)$. Comparison of serum concentrations of soluble form of P-selectin between the AAC and AT/AU patients showed no statistically significant difference $(p=0.2865)$. Comparing the serum concentrations of the soluble form of P-selectin between AA patients in the active phase with patients in inactive phase, no statistically significant difference was observed $(p=0.2670)$.

The comparison between analyzed groups of AA patients in relation to selectin $E, P$ and $L$ is summarized in Table 2.

\section{Discussion}

Alopecia areata is a chronic disease mediated by T lymphocytes and despite numerous studies, its pathogenesis still has not been fully elucidated. The histological examination of AA patients' skin reveals the large cell infiltration around the hair follicles with a high number of T cells and other inflammatory cells [28]. Their presence may lead to the release of cytokines within the hair follicle [29]. Cormia and Ernyey demonstrated within bald skin the presence of inflammatory infiltrate also around blood vessels with a thickening of their walls [30]. Another interesting pathogenetic issue is related to elevated serum concentrations of selectins, which are known as first adhesion molecules involved in lymphocyte migration through the vessel wall and may reflect vascular abnormalities [31].

One of the molecules analyzed in this report was E selectin that plays an important role in guiding $T$ lymphocytes to the sites of inflammation [32-34]. This selectin also is a ligand of the antigens found on the surface of inflammatory cells, including cutaneous lymphocyte-associated antigen (CLA). To date, no study has been published assessing the concentration of E-selectin in the serum of patients with AA. Previous reports focused mainly on the clinical expression of E-selectin in the skin of patients with AA [35-38]. Toyoda et al. observed an increased expression of this molecule on perifollicular endothelial cells in skin samples obtained from the center of the AA areas [38]. Ghersetich et al. in immunohistochemical studies also found an increased E-selectin expression, including the skin of the scalp not involved in the disease process (seemingly healthy skin), but only in the active phase of the disease [37]. This author suggests the existence of subclinical AA, which is characterized by no hair loss, but in immunohistochemistry by presence of numerous inflammatory cells around the blood vessels within seemingly healthy skin and spared perifollicular region [37]. Another author observed a high expression of E-selectin in a patient with 14 years' history of AA, which was comparable to one observed in psoriatic skin [36].

In this study we noted a significantly higher serum level of soluble form of E-selectin in patients with AA (39.1 $\pm 17.5 \mathrm{ng} / \mathrm{ml})$ compared to healthy controls $(27.7 \pm 12.1 \mathrm{ng} /$ $\mathrm{ml})$. It can therefore be assumed that its elevated level, most likely induced by scaling of the selectin from the surface of endothelial cells, may be indicative of an ongoing inflammatory process in the vessels [31]. We also detected a higher average concentration of E-selectin in patients with more severe AA, what may be related to the severity of lymphocytic infiltration in various forms of AA. Dy and Whiting reported a lower lymphocytes concentration in AAC and greater in AT/AU [39]. Additionally, we observed a statistically significant difference in concentration of the soluble form of E-selectin between active and inactive

Table 2. Comparison of soluble forms of E, P, L-selectins between analyzed populations

\begin{tabular}{lccc}
\hline Analyzed populations & \multicolumn{3}{c}{ Value of $p$} \\
\cline { 2 - 4 } & E-selectin & P-selectin & L-selectin \\
\hline AA/healthy & $0.0003^{*}$ & $0.0026^{*}$ & $0.0275^{*}$ \\
\hline AAC/healthy & $0.0327^{*}$ & 0.0543 & $0.0153^{*}$ \\
\hline AT AU/healthy & $0.0001^{*}$ & $0.0005^{*}$ & 0.1842 \\
\hline AAC/AT/AU & $0.0011^{*}$ & $0.0063^{*}$ & 0.2865 \\
\hline AA active/AA inactive & $<0.0001^{*}$ & 0.1577 & 0.2670 \\
\hline${ }^{*}$ Statistically significant difference. & &
\end{tabular}


phase of the disease, with higher values observed in the former form. These results suggest that E-selectin plays a significant role in the development of disease and may be a marker of a more severe type of AA. In this context and given the difficulties in the treatment of AA, we should consider the possibility of initiation of treatment aimed at inhibiting the activity of selectins, including E-selectin.

Another analyzed adhesion molecule was L-selectin which is detected on the surface of lymphocytes, granulocytes and monocytes [40]. Its expression decreases after cell activation. The inflammatory mediators peel of L-selectin from leukocyte cell surface what leads to the increase its soluble forms [41, 42]. Soluble forms of this molecule are probably capable of inhibiting the adhesion processes [41]. Until now there have been no studies regarding serum concentrations of soluble form of L-selectins and its expression within skin of AA patients. In the present research we observed significantly higher levels of soluble form of L-selectin in the serum of patients with AA $(1676.9 \pm 624.1 \mathrm{ng} / \mathrm{ml})$ than in the control group $(1424.6$ $\pm 765.8 \mathrm{ng} / \mathrm{ml}$ ). Also, serum concentrations of soluble form of L-selectin was significantly higher in patients with AT/ AU $(1990.3 \pm 771.3 \mathrm{ng} / \mathrm{ml})$ compared to patients with AAC $(1488.8 \pm 426.1 \mathrm{ng} / \mathrm{ml})$. We found no significant difference in the concentration of L-selectin depending on the activity of the disease. However, the participation of adhesion molecules in inflammation is a self-limiting process. It is known that interactions of selectins, both soluble and associated with the cell membrane forms, can clearly affect the activity of the inflammatory process. It is believed that the serum form of L-selectin is probably a component of the buffer system, which limits the process of rolling leukocytes and thus their migration to sites of inflammation $[41,42]$. High concentrations of soluble L-selectins in patients with AA presented in our project can also limit the migration of leukocytes to sites of inflammation. It seems that evaluation of expression of this selectins in the skin of AA patients would be beneficial.

The third selectin evaluated in this project was P-selectin. This molecule is expressed within the surface of activated platelets and endothelial cells. The literature data indicate that there are many forms of soluble P-selectin, which originate predominantly from the exfoliation of the cell surface $[43,44]$. Those serum forms are still functionally active and exhibit procoagulant activity being engaged in the development of vascular thrombosis [44]. To date, there is no published research on the assessment of P-selectin in AA. In our study, the average concentration of the soluble form of P-selectin in the serum of AA patients was $96.4 \pm 44.8 \mathrm{ng} / \mathrm{ml}$ and it turned out to be higher than in the control group. Considering the severity of the disease process, there was no significant difference in mean P-selectin concentrations between patients with AAC and AT/AU. Thus, the measurement of P-selectin serum level seems to be inapplicable to assess the disease severity. On the other hand, significantly higher levels of P-selectin in the serum of AA patients may confirm the theory of vascular pathogenesis of AA. An interesting fact is that P-selectin is capable to compensate the absence of E-selectin. The expression of both selectins is on the surface of endothelial cells. Also it was revealed that P-selectin during the inflammatory response can independently initiate movement of white blood cells [44]. Its significantly higher and sustained expression has been demonstrated in diseases of chronic stimulation of endothelial cells, like in vascular thrombosis [45] and also in patients suffering from coronary heart disease, peripheral vascular disease, acute myocardial infarction and stroke. The effect of interaction between P-selectin and its ligand located on leukocytes (PSGL-1) is aggregation of platelets and leukocytes, what leads to clotting [45]. What is interesting, in the biopsy taken from AA patients, Cormia and Ernyey observed the presence of blood clots in the light of capillaries as well as thickening of their wall. This may lead to partial occlusion of their lumen [30]. It is also suggested that these abnormalities may impair angiogenesis. The physiological hair follicle neovascularization process plays an important role in increasing the hair papilla during phases of its normal growth $[3,30]$.

\section{Conclusions}

This study shows that selectins may play an important role in the pathogenesis of AA, especially E and $L$ ones. Serum concentrations of soluble forms of $E$ - and L-selectin correlated with the severity of the disease, while E-selectin with activity of AA. Significantly higher concentrations of all tested selectins observed in this study should be considered in regards of new therapeutic approaches aimed at blocking their activity. These drugs are now being tested with a good effect in clinical trials in the group of patients with psoriasis [46], what gives hope for their future use in patients with hair loss. What is more, we found that selectins serum levels in analyzed AA population were higher than observed in our psoriatic patients (our unpublished data) and that makes such anti-selectin therapy especially useful.

\section{Conflict of interest}

The authors declare no conflict of interest.

\section{References}

1. Lever WF. Histopathology of the skin. Gundula Scharnburg-Lewer 1990; 223-4.

2. Wang E, McElwee KJ. Etiopathogenesis of alopecia areata: why do our patients get it? Dermatol Ther 2011; 24: 337-47.

3. Popchristov P, Konstantinov A, Obreshkova E. The blood vessels of the scalp in patients with alopecia areata before and after corticosteroid therapy. Br I Derm 1968; 80: 753-7.

4. Groves RW, Kapahi P, Barker JN, et al. Detection of circulating adhesion molecules in erythrodermic skin disease. J Am Acad Dermatol 1995; 32: 32-6. 
5. Morita H, Kitano Y, Kawasaki N. Elevation of serum-soluble E-selectin in atopic dermatitis. J Dermatol Sci 1995; 10: 145-50.

6. Denton CP, Bickerstaff, Shiwen X, et al. Serial circulating adhesion molecule levels reflect disease severity in systemic sclerosis. Br J Rheumatol 1995; 34: 1048-54.

7. Carmona C, Pineyro I, Martinez M, et al. Soluble E-L-selectin levels in psoriatic patients treated with cyclosporine. Eur J Dermatol 1996; 6: 297-9.

8. Yamamoto T, Matsuuchi M, Watanabe K, et al. Correlation of soluble ICAM-1 and E-selectin in the peripheral blood of patients with generalized pustular psoriasis and their immunohistochemical localization. Eur J Dermatol 1997; 7: 89-92.

9. d'Auria L, Cordiali FP, Pietravelle M, et al. The serum levels of sE-selectin are increased in patients with bullous pemphigoid or pemphigus vulgaris. Correlation with the number of skin lesions and recovery after corticosteroid therapy. $\mathrm{Br}$ J Dermatol 1997; 137: 59-64.

10. Ihm CW, Han JH. Diagnostic value of exclamation mark hairs. Dermatology 1993; 186: 99-102.

11. Kitamura T, Tamada Y, Kato M, et al. Soluble E-selectin as a marker of disease activity in pustulosis palmaris et plantaris. Acta Derm Venereol 1999; 79: 462-4.

12. Furue M, Koga T, Yamashita N. Soluble E-selectin and eosinophil cationic protein are distinct serum markers that differentially represent clinical features of atopic dermatitis. $\mathrm{Br}$ J Dermatol 1999; 140: 67-72.

13. Erdem T, Güleç Al, Aktas A, et al. Increased serum level of P-selectin in patients with lichen planus. Yonsei Med J 2004; 45: 215-8.

14. Lis-Święty A, Rogala-Poborska I, Syguła E. Serum soluble interleukin-6 receptor concentration measurement in patients with systemic sclerosis before and after immunosupressive therapy. Postep Derm Alergol 2006; 23: 67-72.

15. Lis-Święty A, Brzezińska-Wcisło L, Wcisło-Dziadecka D, Serum E-selectin measurement in patients with Raynaud's disease and systemic sclerosis. Postep Derm Alergol 2005; 22: $250-4$.

16. Borska L, Fiala Z, Krejsek J, et al. Selected immunological changes in patients with Goeckerman's therapy TNF-alpha, sE-selectin, sP-selectin, sICAM-1 and IL-8. Physiol Res 2006; 55: 699-706

17. Caproni M, Volpi W, Giomi B, et al. Cellular adhesion molecules in chronic urticaria: modulation of serum levels occurs during levocetirizine treatment. Br J Dermatol 2006; 155: 1270-4.

18. Kuryliszyn-Moskal A, Klimiuk PA, Ciolkiewicz M, et al. Clinical significance of selected endothelial activation markers in patients with systemic lupus erythematosus. J Rheumatol 2008; 35: 1307-13.

19. Olewicz-Gawlik A, Danczak-Pazdrowska A, Klama K, et al. Increased serum levels of solube E-selectin and P-selectin in patients with localized scleroderma. 17th Congress of the European Academy of Dermatology and Venereology. Paris 17-21 September 2008. Poster 0238.

20.Emel G, Nuri Ö, Örüm H, et al. Elevated platelet-monocyte complexes in patients with psoriatic arthritis. Plateles 2009; 20: 493-7.

21. Long JW, Tao J, Pi XM, et al. Effect of narrow-band UVB phototherapy on soluble cell adhesion molecules in patients with psoriasis vulgaris. J Int Med Res 2010; 38: 1507-12.

22. Ciołkiewicz M, Kuryliszyn-Moskal A, Klimiuk PA. Analysis of correlations between selected endothelial cell activation markers, disease activity, and nailfold capillaroscory microvascular changes in systemic lupus erythematosus patients. Clin Rheumatol 2010; 29: 175-80.
23. Burgdorf WHC, Plewig G, Wolff HH. Dermatology. Czelej, Lublin 2010; 1074-6.

24. Kamińska-Winciorek G. Dermatologia cyfrowa. In: Kapilaroskopowa ocena mikrokrążenia i trichoskopia cyfrowa. Cornetis, Wrocław 2008; 85-99, 101-112.

25. Brzezińska-Wcisło L, Lis-Święty, Wcisło-Dziadecka D, et al. The most common diseases of scalp in childhood. Postep Derm Alergol 2009; 26: 257-69.

26. Caproni M, Volpi W, Giomi B, et al. Cellular adhesion molecules in chronic urticaria: modulation of serum levels occurs during levocetirizine treatment. Br J Dermatol 2006; 155: 1270-4.

27. Olsen EA, Hordinsky MK, Price VH, et al. Alopecia areata investigational assessment guidelines - Part II. J Am Acad Dermatol 2004; 51: 440-7.

28. Lever WF. Histopathology of the skin. Gundula Scharnburg-Lewer 1990; 223-4.

29. Joss-Wichman E, Broniarczyk-Dyła G. Current views on etiology of alopecia areata. Postep Derm Alergol 2005; 22: 189-98.

30.Cormia FE, Ernyey A. Circulatory changes in alopecia. Arch Dermatol 1961; 84: 114-31.

31. Blann AD, Herrick A, Jayson MIV. Altered levels of soluble adhesion molecules in rheumatoid arthritis, vasculitis and systemic sclerosis. Br J Rheumatol 1995; 34: 814-9.

32. Gilhar A, Paus R, Kalish RS. Lymphocytes, neuropeptides and genes involved in alopecia areata. J Clin Invest 2007; 117: 2019-27.

33. Yano S, Nakamura K, Tamaki K. Analysis of the expression of cutaneous lymphocyte-associated antygen on the peripheral blood and cutaneous lymphocytes of alopecia areata patients. Acta Derm Venereol 2002; 82: 82-5.

34. Lacueva L, Guilabert A, Ferrando J. The expression of cutaneous lymphocyte-associated antigen (CLA) in alopecia areata. Eur J Dermatol 2005; 15: 201-2.

35. Nickoloff BJ, Griffiths CE. Aberrant intercellular adhesion molecule-1 (ICAM-1) expression by hair-follicle epithelial cells and endothelial leukocyte adhesion molecule-1 (ELAM-1) by vascular cells are important adhesion-molecule alterations in alopecia areata. J Invest Dermatol 1991; 96: 91-2.

36. Rilo HLR, Carroll PB, Subbotin V, et al. E-selectin and interleukin-2 receptor alpha-chain expression in alopecia universalis. Acta Derm Venereol 1994; 74: 33-6.

37. Ghersetich I, Campanile G, Lotti T. Alopecia areata: immunohistochemistry and ultrastructure of infiltrate and identification of adhesion molecule receptors. Int J Dermatol 1996; 35: 28-33.

38. Toyoda M, Makino T, Kagoura M, et al. Expression of neuropeptide-degrading enzymes in alopecia areata: an immunohistochemical study. Br J Dermatol 2001; 144: 46-54.

39. Dy LC, Whiting DA. Histopathology of alopecia areata, acute and chronic: why it important to the clinician? Dermatol Ther 2011; 24: 369-74.

40. Fremont AJ. Adhesion molecules. J Clin Pathol 1998; 263: 8468-9.

41. Spertini O, Schleiffenbaum B, White Owen C, et al. ELISA for quantitation of L-selectin shed from leukocytes in vivo. J Immunol Methods 1992; 156: 115-23.

42. Schleiffenbaum B, Spertini O, Tedder TF. Soluble L-selectin is present in human plasma at high levels and retains functional activity. J Cell Biol 1992; 119: 229-38.

43. Ushiyama S, Laune TM, Moore KL, et al. Structural and functional characterization of monometric soluble P-selectin and comparison with membrane P-selectin. J Biol Chem 1993 ; 268: 15229-37. 
44. Beeh KM, Beier J, Meyer M, et al. Bimosiamose, an inhaled small-molecule pan-selectin antagonist, attenuates late asthmatic reactions following allergen challenge in mild asthmatics: a randomized, double-blind, placebo-controlled clinical cross-over-trial. Pulm Pharmacol Ther 2006; 19: 233-41.

45. Dymicka-Piekarska V, Matowicka-Karna J, Osada J. Changes in platelet CD 62P expression and soluble P-selectin concetration in surgically treated colorectal carcinoma. Adv Med Sci 2006; 51: 304-8.

46. Erhardt C, Kneuer C, Bakowsky U. Selectins-an emerging target for drug delivery. Adv Drug Delivery Rev 2004; 56: 527-49. 